Abstract SAT0256 - Table 1. LSM (SE) changes from baseline in patient-reported outcomes and proportion of patients reporting improvements in HAQ-DI $\geq$ MCID at Month 6 and Month 12 in ORAL Strategy

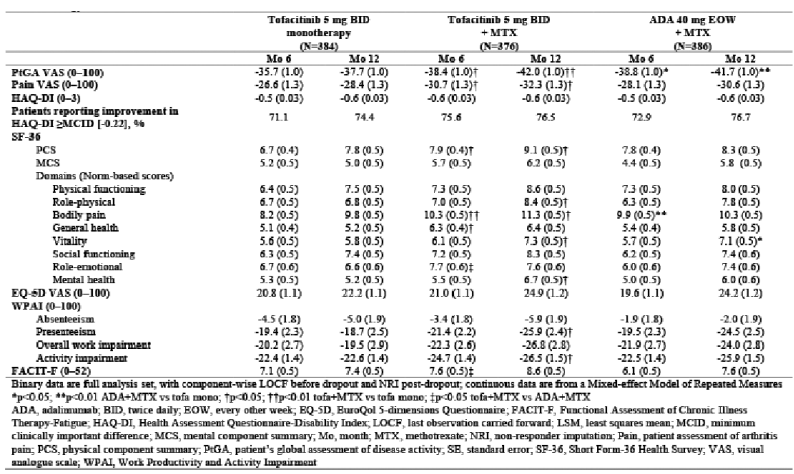

Conclusions: MTX-IR patients with RA reported PRO improvements with all 3 treatment regimens that were clinically meaningful, comparable for tofacitinib +MTX and adalimumab +MTX and numerically higher with combination therapy than with tofa mono. Nominal $p$ values should be interpreted with caution as they were not controlled for Type 1 error.

Acknowledgements: Study sponsored by Pfizer Inc. Medical writing support was provided by D Binks of CMC and funded by Pfizer Inc.

Disclosure of Interest: V. Strand Consultant for: AbbVie, Amgen, AstraZeneca, Bayer, Boehringer Ingelheim, Bristol-Myers Squibb, Celltrion, Corrona, Eli Lilly, Janssen, Merck, Novartis, Pfizer Inc, Regeneron, Samsung, Sanofi, and UCB, E. Mysler Grant/research support from: AbbVie, Bristol-Myers Squibb, Eli Lily, Janssen, Medlmmune, Pfizer Inc, and Roche, Consultant for: AbbVie, Bristol-Myers Squibb, Eli Lily, Janssen, Medlmmune, Pfizer Inc, and Roche, Speakers bureau: AbbVie, Bristol-Myers Squibb, Eli Lily, Janssen, Medlmmune, Pfizer Inc, and Roche, R. Moots Grant/research support from: Biogen, Bristol-Myers Squibb, Chugai, Novartis, Pfizer Inc, Roche, Sandoz, and UCB, Consultant for: Biogen, Bristol-Myers Squibb, Chugai, Novartis, Pfizer Inc, Roche, Sandoz, and UCB, Speakers bureau: Biogen, Bristol-Myers Squibb, Chugai, Novartis, Pfizer Inc, Roche, Sandoz, and UCB, G. Wallenstein Shareholder of: Pfizer Inc, Employee of: Pfizer Inc, R. DeMasi Shareholder of: Pfizer Inc, Employee of: Pfizer Inc, D. Gruben Shareholder of: Pfizer Inc, Employee of: Pfizer Inc, K. Soma Shareholder of: Pfizer Inc, Employee of: Pfizer Inc, N. likuni Shareholder of: Pfizer Inc, Employee of: Pfizer Inc, R. Fleischmann Grant/research support from: AbbVie, Amgen, AstraZeneca, Bristol-Myers Squibb, Celltrion, Genentech, GSK, Janssen, Lilly, Novartis, Pfizer Inc, Sanofi-Aventis, and UCB, Consultant for: AbbVie, Amgen, AstraZeneca, Bristol-Myers Squibb, Celltrion, Genentech, GSK, Janssen, Lilly, Novartis, Pfizer Inc, Sanofi-Aventis, and UCB

DOI: 10.1136/annrheumdis-2018-eular.1312

\section{SAT0257 A PHASE 2B/3 RANDOMISED, PLACEBO-CONTROLLED, DOUBLE-BLIND STUDY OF UPADACITINIB, A SELECTIVE JAK1 INHIBITOR, IN JAPANESE PATIENTS WITH ACTIVE RHEUMATOID ARTHRITIS AND INADEQUATE RESPONSE TO CONVENTIONAL SYNTHETIC DMARDS}

Y. Tanaka ${ }^{1}$, T. Takeuchi ${ }^{2}$, K. Yamaoka ${ }^{2}$, M. Oribe ${ }^{3}$, M. Kawano ${ }^{4}$, Y. Zhou ${ }^{5}$, A. A. Othman ${ }^{5}$, A.L. Pangan ${ }^{5}$, S. Kitamura ${ }^{6}$, N. Matsuda 6 , S. Meerwein ${ }^{7}$, H. Kameda ${ }^{8}$. ${ }^{1}$ Univ of Occupational and Environmental Health, Kitakyushu; ${ }^{2}$ Keio Univ School of Medicine, Tokyo; ${ }^{3}$ Oribe Clinic of Rheumatism and Medicine, Oita; ${ }^{4}$ Honjo Rheumatism Clinic, Takaoka, Japan; ${ }^{5}$ AbbVie, N Chicago, USA; ${ }^{6}$ AbbVie GK, Tokyo, Japan; ${ }^{7}$ AbbVie Deutschland GmbH and Co KG, Ludwigshafen, Germany; ${ }^{8}$ Toho Univ (Ohashi Medical Center), Tokyo, Japan

Background: Upadacitinib (UPA) is an oral, JAK1-selective inhibitor found to be effective in Phase 2 and 3 studies in rheumatoid arthritis (RA) patients with inadequate response or intolerance to csDMARDs and bDMARDs. ${ }^{1-4}$

Objectives: To evaluate the efficacy and safety of UPA in Japanese active RA patients with inadequate response to csDMARDs (csDMARD-IR).

Methods: During the 12 week double-blind period, patients on stable csDMARDs were randomised to receive UPA $7.5,15$ or $30 \mathrm{mg}$ once daily or PBO (1:1:1:1). The primary endpoint was proportion of patients achieving ACR20 at Wk 12 (NRI). Results: Of 197 patients treated, 187 completed the double-blind period. At Week 12, more patients receiving UPA 7.5, 15 and $30 \mathrm{mg}$ vs PBO met ACR20 $(75.5 \%, 83.7 \%, 80 \%$ vs $42.9 \%, p<0.001)$. A significant difference in ACR20 was observed as early as Week 1 (table 1). The more stringent responses, such as ACR50/70, DAS28-CRP $\leq 3.2$, were achieved by significantly higher proportions of patients on UPA vs PBO with more patients on UPA $15 \mathrm{mg}$ and $30 \mathrm{mg}$ achieving these responses vs UPA $7.5 \mathrm{mg}$ (Table). At Week 12, patients receiving UPA vs PBO had greater improvements from baseline $(p<0.001)$ in DAS28-CRP $(-2.08$,$2.39,-2.41$ vs -0.79$)$ and $\mathrm{HAQ}-\mathrm{DI}(-0.41,-0.45,-0.49$ vs -0.10$)$.

Overall adverse events (AE), serious AEs, infections (including serious infections, opportunistic infections and herpes zoster) were numerically higher in UPA $30 \mathrm{mg}$. There were no events of pulmonary embolism, deep vein thrombosis, tuberculosis or malignancy and there were no deaths. Mean haemoglobin levels improved with UPA $7.5(+0.35 \mathrm{~g} / \mathrm{dL})$ and remained stable with UPA $15(-0.03 \mathrm{~g} /$ $\mathrm{dL})$ vs UPA $30(-0.54 \mathrm{~g} / \mathrm{dL})$ and PBO $(-0.17 \mathrm{~g} / \mathrm{dL})$. CPK elevations and lymphopenia occurred more frequently in UPA $30 \mathrm{mg}$.

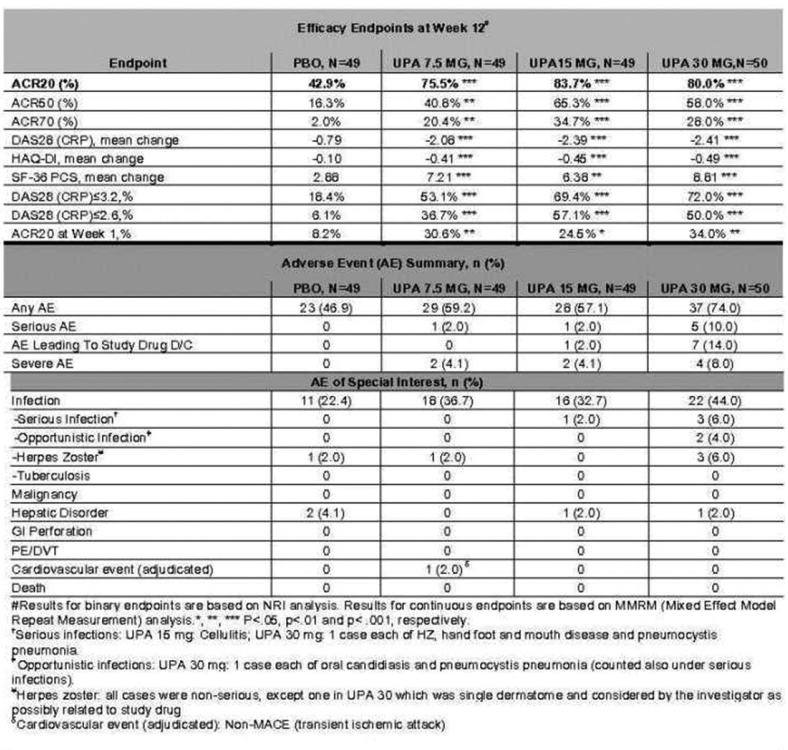

Conclusions: In this Japanese RA csDMARD-IR population, the efficacy of UPA was demonstrated, with better responses for more stringent endpoints on UPA $15 \mathrm{mg}$ and $30 \mathrm{mg}$ vs $7.5 \mathrm{mg}$. The frequency of overall AEs was numerically higher in UPA $30 \mathrm{mg}$. Overall, safety and tolerability were consistent with Phase 2 and 3 studies to date.

\section{REFERENCES}

[1] Burmester, et al. Arth Rheum 2017;69:S10.

[2] Genovese, et al. Arth Rheum 2017;69:S10.

[3] Kremer, et al. Arth Rheum 2016;68(12).

[4] Genovese, et al. Arth Rheum 2016;68(12).

Acknowledgements: AbbVie, Inc was the study sponsor, contributed to study design, data collection, analysis and interpretation, and to writing, reviewing, and approval of final version. Statistical support: Masuyuki Yokoyama, Medical writing support:Naina Barretto, both employees of AbbVie.

Disclosure of Interest: Y. Tanaka Grant/research support from: MitsubishiTanabe Pharma Corporation, Takeda Pharmaceutical Company Ltd, BristolMyers Squibb Company, Chugai Pharmaceutical Co Ltd, Astellas Pharma Inc, AbbVie GK, MSD K.K., Daiichi Sankyo Company Ltd, Pfizer Japan Inc., Kyowa Hakko Kirin Co., Ltd, Eisai Co., Ltd, Ono Pharmaceutical Co., Ltd, Speakers bureau: Daiichi Sankyo Company Ltd, Astellas Pharma Inc, Pfizer Japan Inc., Mitsubishi-Tanabe Pharma Corporation, Bristol-Myers Squibb Company, Chugai Pharmaceutical Co Ltd, YL Biologics, Eli Lilly Japan KK, Sanofi KK, Janssen Pharmaceutical KK, UCB Japan Co., Ltd, T. Takeuchi Grant/research support from: Pfizer Japan Inc., Eisai Co., Ltd, Astellas Pharma Inc., AbbVie GK, Asahi Kasei Pharma Corporation, Nippon Kayaku Co., Ltd, Taisho Toyama Pharmaceutical Co., Ltd., Takeda Pharmaceutical Company Ltd, AYUMI Pharmaceutical Corporation, Takahashi Industrial and Economic Research Foundation, Paid instructor for: Astellas Pharma Inc., AbbVie GK, Eisai Co., Mitsubishi-Tanabe Pharma Corporation, Chugai Pharmaceutical Co Ltd, Bristol-Myers Squibb Company, UCB Japan Co., Ltd, Speakers bureau: Mitsubishi-Tanabe Pharma Corporation, Janssen Pharmaceutical KK, Chugai Pharmaceutical Co Ltd, Astellas Pharma Inc., AbbVie GK, Eisai Co., Ltd, Bristol-Myers Squibb Company, Daiichi Sankyo Company Ltd, Eli Lilly Japan KK, Pfizer Japan Inc., K. Yamaoka Speakers bureau: Pfizer Japan Inc., Chugai Pharmaceutical Co Ltd, Takeda Pharmaceutical Company Ltd, Astellas Pharma Inc, AbbVie GK, Bristol-Myers Squibb Company, Mitsubishi-Tanabe Pharma Corporation, M. Oribe: None declared, M. Kawano: None declared, Y. Zhou Shareholder of: AbbVie, Employee of: AbbVie, A. Othman Shareholder of: AbbVie, Employee of: AbbVie, A. Pangan Shareholde of: AbbVie, Employee of: AbbVie, S. Kitamura Shareholder of: AbbVie, Employee 
of: AbbVie, N. Matsuda Shareholder of: AbbVie, Employee of: AbbVie, S. Meerwein Shareholder of: AbbVie, Employee of: AbbVie, H. Kameda Grant/research support from: AbbVie GK, Astellas Pharma Inc, Bristol-Myers Squibb Company, Chugai Pharmaceutical Co Ltd, Mitsubishi-Tanabe Pharma Corporation and Novartis Pharma KK., Speakers bureau: AbbVie GK, Bristol-Myers Squibb Company, Chugai Pharmaceutical Co Ltd, Eli Lilly Japan KK, Janssen Pharmaceutical KK, Mitsubishi-Tanabe Pharma Corporation, Novartis Pharma KK and Sanofi KK DOI: 10.1136/annrheumdis-2018-eular.4302

\section{SAT0258 WEEKLY SPLIT DOSE COMPARED WITH SINGLE DOSE ORAL METHOTREXATE REDUCED POLYGLUTAMYLATION IN RED BLOOD CELLS AND INCREASED THE RISK OF ADVERSE EVENTS IN PATIENTS WITH RHEUMATOID ARTHRITIS}

Y. Yoshioka ${ }^{1}$, K. Katayama ${ }^{2}$, T. Kasama ${ }^{3}$, M. Sato ${ }^{4}$, S. Ohno ${ }^{5}$, Y. Amasaki ${ }^{6}$, H. Kataoka ${ }^{7}$, D. Kanai ${ }^{1}$, A. Suda ${ }^{1}$, M. Okamoto ${ }^{8}$, M. Sasano ${ }^{8}$, S. Nagaoka ${ }^{1}$, A. Sagawa ${ }^{9}$ on behalf of ADDMe trial Group. ${ }^{1}$ Yokohama Minami Kyosai Hospital, Yokohama; ${ }^{2}$ Katayama Orthopedic Rheumatology Clinic, Asahikawa; ${ }^{3}$ Showa University Koto-Toyosu Hospital, Tokyo; ${ }^{4}$ Ohashi Tani Orthopedic Hospital, Gifu; ${ }^{5}$ Yokohama City University Medical Center, Yokohama; ${ }^{6}$ KKR Sapporo Medical Center, ${ }^{7}$ Sapporo City General Hospital, Sapporo; ${ }^{8}$ AYUMI pharmaceutical. Corporation, Kyoto; ${ }^{9}$ Sagawa Akira Rheumatology Clinic, Sapporo, Japan

Background: Methotrexate (MTX) is a well-known anchor drug for rheumatoid arthritis (RA); however, dose regimens vary. We previously reported in EULAR2015 that split dose weekly oral methotrexate induced elevation of AST and ALT in association with elevation of MTX with 2 glutamates (MTX-PG2) in a single-centre trial.

Objectives: We performed a multi-centre randomised controlled trial to compare the incidence of adverse events using single and split dose regimens.

Methods: Six hospitals and 2 rheumatology clinics participated in this study. Seventy-eight patients with insufficient control on MTX $8 \mathrm{mg} /$ week were randomly assigned to 2 groups, i.e., a single weekly dose regimen with 39 patients and a 3 dose per week regimen with 39 patients. The MTX dose in all patients was gradually increased to $16 \mathrm{mg} /$ week. The primary endpoint was the occurrence of liver dysfunction during the observation period ( 20 weeks). Other endpoints included the incidence of adverse events and the changes from baseline in the disease activity score (DAS28) based on ESR or CRP, the Simplified Disease Activity Index (SDAI), and MTX-PG at week 20.

Results: There were no differences between the groups in baseline data and MTX dose at 20 weeks (single dose: $10.2 \pm 0.8$ vs. 3 -dose: $10.2 \pm 0.9 \mathrm{mg} /$ week). Liver dysfunction occurred in 3 patients $(7.7 \%)$ receiving the single dose regimen and in 5 patients $(13.2 \%)$ receiving the 3 -dose regimen, but there was no significant difference in the incidence in both groups $(p=0.455)$. There was a significant difference in the incidence of adverse events (gastrointestinal disorder was most common) between single dose (11 patients, 28.9\%) and 3-dose (20 patients, $52.6 \%)$ regimens $(p=0.036)$. There was no significant difference in the changes from baseline in DAS28-ESR (-1.55 vs. -1.36$)$, DAS28-CRP (-1.31 vs. -1.26$)$, or SDAI ( -9.45 vs. -10.11$)$. Compared to the single dose regimen, MTX-PG2 was significantly increased in the 3-dose regimen, and MTX-PG3, -PG4, and PG5 were significantly increased in the single dose regimen (table 1).

Abstract SAT0258 - Table 1. MTX-PG changes from baseline in red blood cells at week 20.

\begin{tabular}{lcccc}
\hline & $\begin{array}{c}\text { Single dose } \\
\text { Mean } \\
(\mathrm{n}=28) \\
(\mathrm{nmol} / \mathrm{L})(1)\end{array}$ & $\begin{array}{c}\text { 3-dose } \\
\text { Mean } \\
(\mathrm{n}=27) \\
(\mathrm{nmol} / \mathrm{L})(2)\end{array}$ & $\begin{array}{c}\text { Difference } \\
((2)-(1)) \\
\text { Mean }(95 \% \mathrm{Cl})\end{array}$ & $\begin{array}{c}\mathrm{P} \\
\text { (Wilcoxon) }\end{array}$ \\
\hline MTX- & 22.95 & 57.9 & $\begin{array}{c}34.95(-56.99, \\
126.89)\end{array}$ & 0.448 \\
PG1 & -1.14 & 17.36 & $18.50(12.73-24.27)$ & $<0.001$ \\
MTX- & 39.24 & 27.83 & $-11.41(-21.51,-$ & 0.032 \\
PG2 & & & $1.32)$ & $<0.001$ \\
MTX- & 15.43 & 5.10 & $-10.33(-15.03,-$ & \\
PG3 & & & $5.63)$ & $<0.001$ \\
MTX- & 3.36 & 0.15 & $-3.22(-4.73,1.69)$ & \\
PG4 & & & &
\end{tabular}

Conclusions: There were no differences in the incidence of liver dysfunction and efficacy according to the oral MTX dose regimen; however, split weekly dosing compared with single weekly dosing reduced polyglutamylation and increased the risk of adverse events.

Acknowledgements: Clinical registration: UMIN000021157

Disclosure of Interest: Y. Yoshioka: None declared, K. Katayama: None declared, T. Kasama: None declared, M. Sato: None declared, S. Ohno: None declared, Y. Amasaki: None declared, H. Kataoka: None declared, D. Kanai: None declared, A. Suda: None declared, M. Okamoto Employee of: AYUMI Pharmaceutical Corporation, M. Sasano: None declared, S. Nagaoka: None declared A. Sagawa: None declared DOI: 10.1136/annrheumdis-2018-eular.5046

\section{SATURDAY, 16 JUNE 2018 \\ Spondyloarthritis - treatment}

\section{SAT0259 LOW RATE OF SPINAL RADIOGRAPHIC PROGRESSION OVER 2 YEARS IN ANKYLOSING SPONDYLITIS PATIENTS TREATED WITH SECUKINUMAB: A HISTORICAL COHORT COMPARISON}

J. Braun $^{1}$, H. Haibel ${ }^{2}$, M. de Hooge ${ }^{3,4}$, R. Landewé ${ }^{5}$, M. Rudwaleit ${ }^{6}$, T. Fox ${ }^{7}$, A. Readie ${ }^{8}$, H.B. Richards ${ }^{7}$, B. Porter ${ }^{8}$, R. Martin ${ }^{8}$, D. Poddubny' ${ }^{2}$, J. Sieper ${ }^{2}$, D. van der Heijde ${ }^{3} .{ }^{1}$ Rheumazentrum Ruhrgebiet, Herne; ${ }^{2}$ Charité Universitätsmedizin Berlin, Berlin, Germany; ${ }^{3}$ Leiden University Medical Centre, Leiden, Netherlands; ${ }^{4}$ VIB Inflammation Research Center, Ghent, Belgium; ${ }^{5}$ Maastricht University Medical Center, Maastricht, Netherlands; ${ }^{6}$ Klinikum Bielefeld, Bielefeld, Germany; ${ }^{7}$ Novartis Pharma AG, Basel, Switzerland; ${ }^{8}$ Novartis Pharmaceuticals Corporation, East Hanover, USA

Background: Secukinumab, a fully human interleukin 17A (IL-17A) inhibitor improved signs and symptoms of ankylosing spondylitis (AS) in patients (pts) in the MEASURE 1 core trial at 2 years and through 4 years in the extension study. ${ }^{1,2}$ A low radiographic progression rate was reported for the modified Stoke Ankylosing Spondylitis Spinal Score ( $\Delta$ mSASSS at $\mathrm{Yr} 2=0.3) .{ }^{1}$ Comparison of anti-TNF agents with historical NSAID-treated cohorts have not shown a significant benefit at 2 years in reducing radiographic progression. ${ }^{3,4}$

Objectives: This retrospective analysis compared spinal radiographic progression over 2 years in the MEASURE 1 cohort of secukinumab-treated AS patients (C1; NCT01358175) vs a historical cohort of biologic-naïve AS pts (ENRADAS [C2; NCT00715091])..$^{5}$

Methods: Baseline $(\mathrm{BL})$ and 2 year $\mathrm{X}$-ray data from the 2 cohorts were com pared. Only data from pts with X-rays at $B L$ and $\mathrm{Yr} 2$ (data capture window for $\mathrm{Yr} 2$ X-rays: $31-744$ days) were included ( $n=168$ [C1], $n=69$ [C2]). X-rays were independently re-evaluated using the mSASSS by 2 reviewers and an adjudicator blinded to the timing and cohorts; averaged values were analysed. Cases with the highest difference in $\triangle$ mSASSS between readers (top 10\%) were adjudicated. The primary outcome was to compare the $\%$ pts with no radiographic progression ( $\Delta$ mSASSS at Year $2 \leq 0$ ) in C1 vs C2. The difference between $\mathrm{C} 1$ and $\mathrm{C} 2$ was analysed using a logistic regression with cohort as a factor and BL mSASSS as a covariate.

Results: BL demographics were comparable across cohorts, with mean age 40.9 vs 42.6 years, and gender $72.8 \%$ vs $66.7 \%$ male in C1 vs C2, respectively. Over 2 years, least squares (LS) mean $\Delta$ mSASSS was 0.55 for C1 vs 0.89 for C2 $(\mathrm{p}=0.185)$ and $\%$ pts with no radiographic progression $(\Delta$ mSASSS at Year $2 \leq 0)$ was slightly higher in C1 vs C2 (table 1).

Abstract SAT0259 - Table 1. Radiographic status at Yr 2

\begin{tabular}{|c|c|c|c|}
\hline & $\begin{array}{c}\text { C1 } \\
\text { (MEASURE } \\
\text { 1) } \\
n=168\end{array}$ & $\begin{array}{c}\mathrm{C2} \\
\text { (ENRADAS) } \\
n=69\end{array}$ & $\begin{array}{l}\text { Odds ratio/difference of LS } \\
\text { mean }(95 \% \mathrm{Cl}), p \text {-value }\end{array}$ \\
\hline BL mSASSS (SD) & $9.55(14.14)$ & $9.95(13.76)$ & \\
\hline mSASSS at $\mathrm{Yr} 2$ (SD) & $\begin{array}{c}10.10 \\
(14.70)\end{array}$ & $\begin{array}{c}10.85 \\
(14.66)\end{array}$ & \\
\hline $\begin{array}{l}\triangle \text { mSASSS over } 2 \text { years, } \\
\text { LS mean (SE) }\end{array}$ & $0.55(0.14)$ & $0.89(0.22)$ & $p=0.185$ \\
\hline $\begin{array}{l}\text { No progression }(\Delta \\
\text { mSASSS } \leq 0), \%\end{array}$ & $61 \%$ & $52 \%$ & $1.43(0.79,2.60), p=0.243$ \\
\hline $\begin{array}{l}\text { No progression }(\Delta \\
\text { mSASSS }<2), \%\end{array}$ & $82 \%$ & $73 \%$ & $1.84(0.90 ; 3.77), p=0.093$ \\
\hline
\end{tabular}

$\mathrm{Cl}$, confidence interval; SD, standard deviation; SE, standard error 